\title{
PEMBELAJARAN PENDIDIKAN AGAMA ISLAM \\ YANG MENYENANGKAN DENGAN MENDONGENG
}

\author{
Yekti Nugroho \\ Mahasiswa Jurusan Tarbiyah Program Magister Pendidikan Agama Islam \\ UIN Sunan Kalijaga Yogyakarta \\ email: yektinugroho416@gmail.com
}

\begin{abstract}
One of the learning strategies for early childhood education is storytelling, storytelling or storytelling, we can also use in teaching Islamic Education learning material. The learning challenge of Islan Religious Education at the level of early childhood is boredom and boredom caused by the stigmatization of teaching the same teacher. Storytelling not only conveys interesting and fun stories for children, but we can also insert moral values and even tell the history of the Prophet, student moral learning, train social sensitivity, perfect memorization of short letters, and the history of Islamic civilization. But of course there is a need for teachers to prepare interesting stories or stories, determine the media to be used such as teaching aids, master character, memorize storylines, present fairy tales with interesting techniques, prepare a comfortable place and prepare and practice before performing at front of children. So that the fairy tales delivered are not only able to meet the needs of children's imagination and fantasy but also can shape the child's personality, character and morals.
\end{abstract}

Keywords: Learning, Education, Islam, Storytelling

A. Pendahuluan

Dalam proses pembelajaran, di samping peserta didik sering mengalami lupa, mereka juga terkadang mengalami masa jenuh (Helmawati, 2014, p. 214). Kejenuhan yang terjadi pada peserta didik bisa disebabkan karena berbagai macam sebab, salah satunya adalah kelelahan dan kebosanan. Rasa bosan muncul ketika anak dituntut untuk menguasai berbagai macam materi, sedangkan strategi dan metode pembelajaran yang digunakan hanyalah monoton, itu-itu saja. Kejenuhan bisa terjadi pada berbagai materi pembelajaran tak terkecuali materi Pendidikan Agama Islam pada anak usia dini. 


\section{Yekti Nugroho}

Pembelajaran Pendidikan Agama Islam kepada anak usia dini menjadi hal yang tidak mudah untuk disampaikan, mengingat mereka masih berada pada fase pra operasional dimana pada masa perkembangan ini bermula ketika anak mulai merepresentasikan dunia dengan kata dan gambar. Ini merefleksikan peningkatan pemikiran simbolis dan melampaui koneksi informasi indrawi dan tindakan fisik. Dimana pada usia ini anak mulai suka mengajukan banyak pertanyaan "mengapa" yang menandai munculnya minat anak untuk mencari tahu mengapa sesuatu itu terjadi (Santrock, 2007, p. 48-52). Sehingga peran orang tua dan guru untuk menjawab, menjelaskan, dan menceritakan segala sesuatu yang mereka tanyakan menjadi sangat penting.

Pendidikan anak usia dini merupakan pendidikan yang sangat mendasar dan strategis dalam pembangunan sumberdaya manusia. Namun diperlukan metode yang tepat yang sesuai karakter anak usia dini agar pesan-pesan yang ingin disampaikan dapat benar-benar dipahami oleh anak untuk bekal kehidupannya di masa depan. Salah satu metode yang dapat diberikan adalah dengan metode bercerita, karena bercerita dapat dijadikan metode untuk menyampaikan nilai-nilai yang berlaku dalam masyarakat (Setyanto, 2012, p. 19).

Salah satu strategi yang bisa kita gunakan untuk menyampaikan materi Pendidikan Agama Islam kepada anak usia dini adalah dengan mendongeng. Budaya bertutur secara langsung ini bisa kita gunakan untuk menarik perhatian siswa agar antusias memperhatikan dan memahami setiap materi yang kita sampaikan khususnya materi yang berkaitan dengan sejarah kebudayaan Islam, kisah nabi dan Rasul, hafalan, pendidikan Akhlak, atau Asbabun nuzul ayat Al-Qur'an.

Meskipun sejumlah buku cerita untuk anak-anak digelar secara visual, dan berbagai macam cerita diekspos dan ditampilkan dilayar televisi dan video, anak-anak tidak pernah kehilangan ketertarikannya terhadap cerita. Cerita menyimpan daya tarik, justru karena ia ditampilkan secara langsung dan alamiah dari ekspresi manusia. Selain itu, cerita dapat digunakan sebagai materi pembelajaran menyimak dan berbicara. Bercerita bermanfaat unuk mendorong anak-anak agar mau mendengarkan dan menunjukkan kemampuannya menggunakan bahasa lisan. Selain itu, cerita juga merupakan cara yang menyenangkan untuk menyebarluaskan sastra tradisional dan cerita masa lalu (Musfiroh, 2008, p. 101).

Cerita bernilai universal, dan pencerita terpenting adalah orang terdekat anak. Anak-anak yang terbiasa menerima suguhan cerita dari orang terdekat pada masa ke- 
cilnya, termasuk guru dan orang tuanya, akan menyukai eksposisi dan piawai dalam memaparkan informasi kepada orang lain kelak setelah mereka dewasa (Musfiroh, 2008, p. 101).

Berdasarkan uraian diatas penulis akan memaparkan bagaimanakah Pembelajaran Pendidikan Agama Islam yang menyenangkan dengan dongeng, arti pentingnya, manfaatnya, persiapannya, teknik penyampaiannya, dan uraian bagaimana pembelajaran Pendidikan Agama Islam dengan mendongeng.

\section{B. Arti Pentingnya Cerita dalam Pendidikan Anak Usia Dini}

Bagi anak-anak, duduk manis menyimak penjelasan dan nasehat merupakan sesuatu yang tidak menyenangkan. Sebaliknya, duduk berlama-lama menyimak cerita atau dongeng adalah aktivitas yang mengasyikkan. Oleh karenanya, memberikan pelajaran dan nasehat melalui cerita atau dongeng adalah cara mendidik yang bijak dan cerdas. Mendidik dan menasehati anak melalui cerita memberikan efek pemuasan terhadap kebutuhan akan imajinasi dan fantasi anak (Musfiroh, 2008, p. 1).

Cerita dapat digunakan oleh orang tua dan guru sebagai sarana mendidik dan membentuk kepribadian anak melalui pendekatan transmisi budaya atau cultural transmision approach. Dalam cerita, nilai-nilai luhur ditanamkan pada diri anak melalui penghayatan terhadap makna dan maksud cerita (meaning and intention of story). Anak melakukan serangkaian kegiatan kognisi dan afeksi, mulai dari interpretasi, komprehensi, hingga inferensiasi terhadap nilai-nilai moral yang terkandung di dalamnya. Melalui kegiatan ini, transmisi budaya terjadi secara alamiah, bawah sadar, dan akumulatif hingga jalin-menjalin membentuk kepribadian anak. Anak memiliki referensi yang mendalam karena setelah menyimak, anak melakukan serangkaian aktivitas kognisi dan afeksi yang rumit dari fakta ceriata seperti nama tokoh, sifat tokoh, latar tempat, dan budaya, serta hubungan sebab akibat dalam alur cerita dan pesan moral yang tersirat di dalamnya. Makna kebaikan, kejujuran, kerjasama misalnya (Musfiroh, 2008, p. 19-20).

Nilai-nilai moral serta pemahaman anak yang disampaikan melalui cerita terjadi secara lebih kuat daripada jika anak mendengarkan nasehat atau paparan. Sebab dalam proses ini anak ikut terlibat masuk dan berimajinasi di dalam alur cerita, seak- 


\section{Yekti Nugroho}

an-akan dia mengalami sendiri kejadia yang sedang ia dengarkan.

Bercerita menjadi sesuatu yang sangat penting bagi anak karena beberapa alasan:

1. Bercerita merupakan alat pendidikan budi pekerti yang paling mudah dicerna anak di samping teladan yang dilihat anak setiap hari.

2. Bercerita merupakan metode dan materi yang dapat diintegrasikan dengan dasar keterampilan lain, yakni berbicara, membaca, menulis, dan menyimak.

3. Bercerita memberi ruang lingkup yang bebas pada anak untuk mengembangkan kemampuan bersimpati dan berempati terhadap peristiwa yang menimpa orang lain. Hal tersebut mendasari anak untuk memiliki kepekaan sosial.

4. Bercerita memberikan contoh pada anak bagaimana menyikapi permasalahan dengan baik, bagaimana melakukan pembicaraan yang baik, sekaligus memberi pelajaran pada anak bagaimana cara mengendalikan keinginan-keinginan yang dinilai negarif oleh masyarakat.

5. Bercerita memberikan barometer sosial pada anak, nilai-nilai apa saja yang diterima oleh masyarakat sekitar, seperti patuh pada perintah orang tua, mengalah pada adik, dan selalu bersikap jujur.

6. Bercerita memberikan pelajaran budaya dan budi pekerti yang memiliki retensi lebih kuat daripada pelajaran budi pekerti yang diberikan melalui penuturan dan perintah langsung.

7. Bercerita memberi ruang gerak pada anak, kapan sesuatu nilai yang berhasil ditangkap akan diaplikasikan.

8. Bercerita memberikan efek psikologis yang positif bagi anak dan guru sebagai pencerita, seperti kedekatan emosional sebagai pengganti figur lekat orang tua.

9. Bercerita membangkitkan rasa ingin tahu anak akan peristiwa atau cerita, alur, plot, dan yang demikian itu menumbuhkan kemampuan merangkai hubungan sebab-akibat dari suatu peristiwa dan memberikan peluang bagi anak untuk belajar menelaah kejadian-kejadian disekelilingnya 
10. Bercerita memberikan daya tarik bersekolah bagi anak karena di dalam bercerita ada efek rekreatif dan imajinatif yang dibutuhkan anak usia dini. Karena cerita membuat anak lebih joy in school dan memiliki kerinduan bersekolah.

11. Bercerita mendorong anak memberikan "makna" bagi proses belajar terurtama mengenai empati sehingga anak dapat mengkonkretkan rabaan psikologis mereka bagaimana seharusnya memandang sesuatu masalah dari sudut pandang orang lain. Dengan kata lain, anak belajar memahami sudut pandang orang lain secara lebih jelas berdasarkan perkembangan psikologis masing-masing. (Musfiroh, 2008, p. 20-21)

Arti pentingnya bercerita bagi pendidikan anak-anak, tidak dapat dilepaskan dari kemampuan guru dalam mentransmisikan nilai-nilai luhur kehidupan dalam bentuk cerita atau dongeng. Kemampuan gurulah sebenarnya yang menjadi tolok ukur kebermaknaan bercerita, tanpa itu dongeng dan cerita tidak akan memberikan makna apa-apa bagi anak (Musfiroh, 2008, p. 21).

\section{Manfaat Cerita Bagi Anak}

Cerita merupakan kebutuhan universal manusia, dari anak-anak hingga orang dewasa. Bagi anak-anak, cerita tidak sekedar memberi manfaat emotif tetapi juga membantu pertumbuhan mereka dalam berbagai aspek. Oleh karena itu, perlu diyakini bahwa bercerita merupakan aktivitas penting dan tidak terpisahkan dalam program pendidikan untuk anak usia dini. Di tinjau dari berbagai aspek, manfaat tersebut akan diuraikan sebagai berikut (Musfiroh, 2008, p. 21).

1. Membantu pembentuka pribadi dan moral anak

Cerita sangat efektif untuk mempengaruhi cara berpikir dan berperilaku anak karena mereka senang mendengarkan cerita walaupun dibacakan secara berulang-ulang. Pengulangan, imajinasi anak, dan nilai kedekatan antara guru atau orang tua membuat cerita menjadi efektif untuk mempengaruhi cara berpikir mereka. Hal itu dibuktikan oleh psikolog Joseph Strayhorn, Jr dalam bukunya The Competent Child. Ia menulis tentang kisah keteladanan positif yang berkaitan dengan masalah anak dalam dunia nyata (Musfiroh, 2008, p. 81).

Anak yang terbiasa memperoleh kebahagiaan melalui berbagai kegiatan, termasuk saat-saat menyimak dongeng, akan tumbuh menjadi pribadi yang lebih hangat, kompromis, dan memiliki kecerdasan interpersonal lebih tinggi daripada anakanak yang tidak memperoleh kesempatan semacam itu. Guru atau orang tua yang 


\section{Yekti Nugroho}

berperan sebagai pencerita memiliki posisi sentral sebagai tempat bertanya bahkan tempat berbagi. Hubungan psikologis ini membuka peluang bagi orang tua dan guru untuk mentransmisikan ajaran moral dan keteladanan pada anak (Musfiroh, 2008, p. 82).

Peran guru sangat penting untuk mampu memaparkan cerita dengan baik, serta dengan penuh kesabaran menjawab setiap pertanyaan dan tanggapan dari anak, untuk membanu pembentukan kepribadian dan moral anak.

2. Membantu Kebutuhan Imajinasi dan Fantasi

Anak-anak membutuhkan penyaluran imajinasi dan fantasi tentang berbagai hal yang selalu muncul dalam pikiran anak. Masa usia pra sekolah merupakan masa-masa aktif anak-anak berimajinasi. Tidak jarang anak mengarang suatu cerita sehingga oleh sebagian orang tua dianggap sebagai kebohongan. Hal ini menunjukkan bahwa sebenarnya, imajinasi anak-anak sedang membutuhkan penyaluran. Salah satu tempat yang tepat adalah cerita (Musfiroh, 2008, p. 83).

Anak-anak terkadang berkhayal atau berfantasi tentang sesuatu yang menyenangkan seperti memiliki rumah bagus, naik mobil balap, bermain ditaman yang indah dan lain sebagainya, melalui dongeng anak dapat berhenti sejenak dari fantasi mereka dan menghadapi fantasi yang disuguhkan guru. Anak memperoleh dunia baru yang sama-sama membutuhkan daya khayal secara tidak langsung, cerita guru berhasil mewadahi khayalan anak, sehingga lebih terarah (Musfiroh, 2008, p. $85)$.

Imajinasi yang dibangun anak saat menyimak cerita memberikan pengaruh positif terhadap kemampuan anak menyelesaikan masalah secara kreatif, imajinasi juga mempengaruhi cara anak menghadapi kehidupan (Musfiroh, 2008, p. 85). Melalui berbagai imajinasi yang anak-anak bayangkan saat menyimak cerita yang disampaikan guru, anak-anak belajar mengenai berbagai cara menghadapi berbagai permasalahan dan menemukan solusi yang tepat atas berbagai persoalan yang ia hadapi.

\section{Memacu Kemampuan Verbal Anak}

Cerita yang baik tidak hanya sekedar menghibur tetapi juga mendidik, sekaligus merangsang berkembangnya komponen kecerdasan linguistik yang paling 
penting, yakni kemampuan menggunakan bahasa. Menyimak cerita yang baik bagi anak, sama artinya dengan melakukan serangkaian kegiatan fonologis, sintaksis, semantik, dan pragmatik. Selama menyimak cerita, anak belajar bagaimana bunyibunyi yang bermakna diajarkan dengan benar, bagaimana kata-kata disusun secara logis dan mudah dipahami, bagaimana konteks berfungsi dalam makna. Hal yang lebih penting, anak juga belajar bagaimana mengambil "pelajaran" gramatika bahasa tentang bagaimana mengambil pola pergiliran bicara (turn taking) yang tepat. Ini berarti, secara tidak langsung, anak telah menajamkan kecerdasan linguistiknya (Musfiroh, 2008, p. 86).

Dalam periode perkembangan pra operasional anak mulai mampu menggunakan kata-kata yang benar dan mampu mengekspresikan kalimat-kalimat pendek tetapi efektif (Syah, 2013, p. 69). Kemempuan verbal anak lebih terstimulasi secara efektif pada saat guru melakukan semacam tes pada anak untuk menceritakan kembali isi cerita. Dari sini anak belajar berbicara, menuangkan kembali gagasan yang didengarnya dengan gayanya sendiri. Anak menyusun kata-kata menjadi kalimat dan menyampaikannya dengan segenap kemampuan. Anak memiliki kemampuan mengucapkan kata dan menceritakan isi cerita dengan bahasanya sendiri. Anak yang menyadari kekuatan kata-kata akan berusaha memperbaiki apabila kurang tepat dan meningkatkannya apabila memperoleh kekuatan. Cerita membuat anak menyadari arti pentingnya berdialog dan menuangkan gagasan dengan kata-kata yang baik (Musfiroh, 2008, p. 87). Metode ini menjadi solusi belajar bahasa yang menyenangkan melalui bercerita di dalam kelas.

4. Merangsang minat membaca dan menulis anak

Pengaruh cerita terhadap kecerdasan bahasa anak diakui oleh Leonhardt. Menurutnya, cerita memancing rasa kebahasaan anak. Anak yang gemar mendengar dan membaca cerita akan memiliki kemampuan berbicara, menulis dan memahami gagasan rumit secara lebih baik. Ini berarti, selain memacu kemampuan berbicara, menyimak cerita juga merangsang minat menulis anak (Musfiroh, 2008, p. 88).

Cerita juga membantu menumbuhkan kemampuan tulis (emergent writing) anak. Cerita dapat menumbuhkan inspirasi anak untuk membuat cerita. Dengan kata lain, cerita dapat menstimulasi anak membuat cerita sendiri. Anak terpacu menggunakan kata-kata yang diperolehnya, dan terpacu menyusun kata-kata dalam kalimat dengan perspektif dongengnya sendiri (Musfiroh, 2008, p. 88). Dari menyimak cer- 


\section{Yekti Nugroho}

ita anak terinspirasi untuk menulis dan mengkreasikan ceritanya dan imajinasinya sendiri.

Bercerita dengan media buku, menjadi stimulasi yang efektif bagi anak-anak, karena pada waktu itu minat baca pada anak mulai tumbuh. Minat itulah yang harus diberi lahan yang tepat, antara lain melalui bercerita (Musfiroh, 2008, p. 94). Membacakan cerita dapat menjadi contoh yang efektif bagi anak bagaimana aktivitas membaca harus dilakukan. Secara tidak langsung anak memperoleh contoh tentang orang yang gemar dan pintar membaca dari apa yang dilihatnya. Apabila sering memperoleh contoh, minat baca anak akan tumbuh dengan sendirinya (Musfiroh, 2008, p. 94). Memberikan buku cerita yang bergambar merupakan salah satu solusi untuk meningkatkan minat baca anak. Mula-mula anak dibacakan cerita dengan media buku, lama-kelamaan anak akan dengan sendirinya tertarik untuk membaca buku cerita itu sendiri.

5. Membuka cakrawala pengetahuan anak

Menyimak cerita mampu meninggalkan kesan yang mendalam dan mampu menggugah semangat anak untuk belajar lebih mendalam. Hal tersebut sejalan dengan pernyataan lenox dalam artikelnya "Storrytelling for Young Children in a Multicultural Word", bahwa bercerita dapat dimanfaatkan unruk menarik minat belajar anak disamping memperluas kesadaran dan pengetahuan tentang keberagaman lingkungan. Cerita juga dapat membantu mengatasi kendala kultural (budaya) disamping juga membangun jembatan pemahaman (Musfiroh, 2008, p. 98).

Baker dan Greene, menyatakan bahwa cerita dapat membawa anak pada sikap yang lebih baik, mempertinggi rasa ingin tahu, misteri, dan sikap menghargai kehidupan. Dengan kata lain, bercerita memberikan jalan bagaimana memahami diri sendiri dan memahami orang lain, serta bagaimana memahami cerita itu sendiri (Musfiroh, 2008, p. 98). Membuka cakrawala anak dapat dilakukan degan metode bercerita, salah satunya ketika kita ingin mengenalkan budaya daerah yang beragam, kita dapat membawakannya dengan cerita-cerita daerah yang kita kemas dengan bahasa dan metode yang mengasyikkan. 


\section{Persiapan Sebelum Bercerita}

Karena pentingnya kegiatan mendongeng, dan kegiatan tersebut perlu dilakukan secara menarik maka mendongeng harus dilaksanakan dengan langkah-langkah tertentu: Memilah dan memilih materi cerita, yang harus diperhatikan adalah memilih judul yang menarik dan mudah diingat. Studi psikolinguistik membuktikan bahwa judul memiliki kontribusi terhadap memori cerita. Judul merupakan elemen cerita yang pertama kali diingat dari pada kalimat-kalimat dalam cerita. Setelah menemukan judul yang tepat, guru dan orang tua baru menemukan materi cerita yang baik. Untuk itu perlu dilakukan kegiatan memilih atau menyeleksi bahan yang meliputi; jenis cerita, bobot cerita, kebaruan cerita, minat anak, dan cerita berbahasa asing. Tidak ada salahnya guru dan orang tua mencari materi cerita yang beragam, sepanjang materi tersebut sesuai untuk usia anak-anak (Musfiroh, 2008, p. 102-111).

Memahami dan menghafal isi cerita, membawakan cerita bukanlah suatu kegiatan yang mudah. Tidak ada seorangpun yang tiba-tiba untuk pertama kalinya dapat bercerita, dapat bercerita dengan menakjubkan. Perlu banyak latihan. Bahkan Garrison Keillot, penyiar radio yang tersohor, mengatakan bahwa biasanya diperlukan sekitar sepuluh hungga duabelas kali kali penyampaian agar suatu cerita dapat disampaikan dengan baik. Karena itu ia menyarankan agar pencerita aktif mencari tradisi lisan, menyimak rekaman cerita, membaca dongeng-dongeng, di samping mempelajari isi dan metode penyempaian cerita (Musfiroh, 2008, p. 111). Terutama bagi guru atau orang tua yang belum terbiasa bercerita sangat perlu menghafalkan cerita diluar kepalayang meliputi, alur cerita, tokoh, dan karakter tokoh.

Menghayati karakter tokoh, kekuatan cerita antara lain terletak pada bagaimana karakter tokoh dimunculkan didalamnya. Semakin sempurna karakter tokoh ditampilkan, semakin menarik cerita itu disimak. Semakin jelas pembawaan karakter tokoh, semakin mudah cerita tersebut diikuti. Pembawaan karakter tokoh yang mendekati kehidupan nyata memudahkan pendengar memahami cerita sekaligus membuat cerita tersebut tampak lebih hidup. Karakter cerita meliputi tokoh atau pelaku cerita dan juga perwatakannya (Musfiroh, 2008, p. 114). Maka seorang pencerita diharapkan mampu menghayati bagaimana perasaan dan emosi tokoh pada saat berdialog, apakah ia sedang marah, bersedih, bahagia, atau kesal.

Tahap terakhir dari upaya menampilkan cerita atau mendongeng dengan baik adalah berlatih dan intropeksi, bagi pencerita pemula yang sebelumnya belum pernah tampil bercerita didepan umum tahapan ini menjadi sangat penting, salah satu caranya bisa dengan berlatih di depan cermin. Apabila pencerita akan menggunakan alat peraga, maka sebelum tampil di depan umum sebaiknya ia berlatih terlebih dahulu tata cara menggunakan alat peraga tersebut dengan baik dan benar. Latihan mampu 


\section{Yekti Nugroho}

menumbuhkan kepercayaan diri dan memperbaiki kualitas bercerita.

\section{E. Teknik Penyajian Cerita}

Persiapan cerita terkait erat dengan teknik penyejian cerita, yakni cara-cara dan alat-alat yang digunakan guru dalam menyampaikan cerita. Yaitu antara lain: memilih dan mempersiapkan tempat, aktivitas bercerita tidak harus dilakukan di dalam kelas. Kegiatan bercerita dapat dilakukan di mana pun asal memenuhi kriteria kebersihan, keamanan, dan kenyamanan. Jika jumlah anak sedikit, bercerita dapat dilakukan diberbagai tempat, seperti diteras, di kelas, di bawah pohon, di ruang tamu, di kebun binatang, bahkan diarena bermain anak-anak. Apabila jumlah anak relatif banyak sebaiknya dipilih tempat yang lebih luas, misalnya ruang kelas, halaman sekolah, dan di tanah lapang. Tempat yang dipilih ditata sedemikian rupa sehingga semua anak dapat melihat gurunya dengan jelas. Apabila ruangan yang disediakan relatif besar dan jumlah anak relatif banyak, tempat dapat ditata semi melingkar, setengah oval, separuh empat persegi panjang dan penataan model U. Penataan ini memungkinkan anak untuk lebih dekat dengan pencerita sehingga komunikasi dapat berjalan dengan lancar. Kehadiran pengeras suara juga dapat membantu lancarnya proses bercerita (Musfiroh, 2008, p. 119-121).

Bercerita dengan alat peraga, cerita dapat dilakukan dengan berbagai alat bantu yang disebut sebagai bercerita dengan alat peraga. Alat peraga yang paling sederhana adalah buku, gambar, papan panel, boneka, dan film bisu. Semua alat membutuhkan keterampilan tersendiri yang memungkinkan penggunaan alat peraga itu berfungsi optimal (Musfiroh, 2008, p. 122).

Bercerita tanpa alat peraga, bercerita tanpa alat peraga disebut juga bercerita secara langsung. Bercerita tanpa alat peraga ini sangat mengandalkan kualitas suara, ekspresi wajah, serta gerak tangan dan tubuh. Pencerita dapat mengambil posisi duduk atau berdiri dalam suasana santai. Teknik ini tidak terkait tempat, waktu, dan orang yang hadir. Kapan, dimana saja, dan berapapun jumlah pendengar dapat dilayani (Musfiroh, 2008, p. 135). Yang terpenting pada saat bercerita tanpa alat peraga ini ialah kepercayaan diri dan kemampuan pencerita menguasai audien. 
Mengekspresikan karakter tokoh, karakter tokoh dapat diekspresikan dengan berbagai cara, antara lain melalui ekspresi visual (raut muka, mulut, mata, air muka, tangan) dan karakter ekspresi suara. Dari pengekspresian ini dapat diketahui ciri-ciri tokoh seperti sifat-sifat tokoh, perasaan, dan emosi tokoh. Ada dua karakter dasar tokoh, yakni karakter baik dan karakter buruk. Yang termasuk karakter baik adalah: penggembira, penolong, tulus hati, mengalah, solider, jujur, pemberani, cerdas, rendah hati, disiplin, sopan, dan rajin. Yang termasuk karakter buruk adalah pemarah, sombong, emosional, tidak sabar, tidak tulus, cerewet, jorok, pemalas, penggusar, kurang ajar, bodoh, culas, egois, dan pencuriga (Musfiroh, 2008, p. 140).

Menirukan bunyi dan karakter suara, yang dimaksud dengan bunyi disini adalah bunyi esensial yang tidak memiliki makna secara linguisti. Bunyi binatang yang dikenal dengan onomotope, bunyi benda jatuh, bunyi ledakan, dan bunyi tabrakan dikategorikan sebagai bunyi dalam hal ini. Walaupun tidak memiliki makna linguistik, buyi-bunyi itu memiliki arti penting dalam cerita. Bunyi-bunyi itu memberikan gambaran sebuah peristiwa, membirikan informasi tokoh fabel apa yang sedang berbicara, dan bagaimana tokoh memulai berbicara. Bunyi-bunyi itu harus dihadirkan dalam cerita. Kehadirannya membuat cerita semakin dramatis dan menarik (Musfiroh, 2008, p. 142).

Menghidupkan suasana cerita, suasana cerita dalam pengertian ini diartikan sebagai keadaan yang menyertai proses terjadinya penceritaan oleh guru kepada siswa. situasi riil yang berhasil ditampilkan antara lain, gaduh, sunyi, antusias, dan penuh kegembiraan. Situasi ini sangat dipengaruhi kemampuan pencerita, misalnya dalam mengoptimalkan dialog antar tokoh, mengoptimalkan klimaks cerita, melibatkan anak dalam cerita melalui pertanyaan dan sapaan, memanfaatkan alat bantu secara optimal dan olah suara, mimik dan pantomimik guna menarik perhatian siswa (Musfiroh, 2008, p. 144).

Memilih diksi dan struktur kalimat, pencerita atau guru harus mengintropeksi penggunaan kalimat dalam bercerita, penggunaan kalimat dalam cerita harus disesuaikan dengan kapasitas pemahaman anak. Kalimat-kalimat yang panjang harus dipotong, kata-kata yang tidak perlu harus dibuang, kata-kata yang penting diulang penggunaannya dalam cerita sehingga anak menjadi paham apa yang mereka dengar (Musfiroh, 2008, p. 146). Pemilihan kata dan kalimat ini harus disesuaikan dengan 


\section{Yekti Nugroho}

tahap perkembangan anak usia dini. Memilih bahasa atau kata-kata yang mudah dan sederhana sehingga anak-anak mampu memahami isi cerita dengan baik.

F. Pembelajaran Pendidikan Agama Islam dengan Mendongeng

Di Indonesia dulunya, dongeng merupakan cerita yang hidup di tengah-tengah masyarakat agraris. Bila bulan purnama datang dengan bentuknya bundar keemasa, anak-anak menggelar tikar di halam rumah. nenek atau kakek mendongeng di atas tikar yang di gelar di halaman rumah dikelilingi oleh cucu-cucunya. Kemudian angin sepoi bertiup mendesirkan daun-daunan. Sungguh, peristiwa yang romantis. Pada saat seperti ini, kerekatan dan kekerabatan menemukan bentuknya dengan berintikan jalinan kasih sayang antara generasi tua dan generasi penerusnya. Dongeng yang kadang-kadang berupa fabel yang mengisahkan tentang satwa akan sangat membantu rasa sayang pada binatang, juga cerita dongeng tentang manusia bisa menjadi contoh teladan bagi kehidupan. Tidak kurang pentingnya adalah cerita-cerita tentang para Rasul dan Nabi serta ketauladanan para sahabat yang mulia. Cerita-cerita yang mengandung ajaran akhlak mulia seperti itu sangat dibutuhkan untuk membentuk kepribadian anak-anak dan para santri. Bahkan dalam pengajian-pengajian, kisah teladan yang mengandung hikmah perlu disampaikan untuk memberi pencerahan (Munawar, 2017, p. 135-136).

Mendongeng dapat dijadikan sebagai salah satu strategi pembelajaran Pendidikan Agama Islam yang menyenangkan bagi siswa. Materi Pembelajaran Akhlak misalnya, ketika kita akan menyampaikan materi mengenai akhlak baik dan buruk, akhlak mahmudah dan majmumah kita coba menampilkan cerita tentang perilaku tokoh yang baik dan buruk. Lalu membiarkan siswa berfikir, yang manakah akhlak yang baik yang patut untuk diteladani, dan yang manakah akhlak yang buruk yang seharusnya di hindari agar tidak melakukannya. Cerita yang kita tampilkan tidak harus melulu cerita nyata dalam kehidupan sehari-hari, agar lebih menarik bisa kita tampilkan cerita tentang hewan (fabel), dongeng daerah (legenda), ataupun cerita-cerita buatan kita sendiri yang memiliki muatan nilai moral bagi siswa.

Mengajarkan Akhlak melalui teks fabel bisa kita jadikan sebagai salah satu solusi pembelajaran agama Islam yang menyenangkan. Teks fabel disebut juga sebagai teks persuasif. Teks persuasif ini terutama mementingkan penerimaan, pembaca, atau 
dalam hal komunikasi lisan adalah pendengar. Usahanya ialah mempengaruhi, meyakinkan, atau mendorong perilaku tertentu, melalui tokoh binatang, pengarang ingin mempengaruhi pembaca agar mencontoh tokoh yang baik dan tidak mencontoh yang tidak baik (Sugihastuti, 1996, p. 21). Sehingga kita dapat menggunakan teks fabel sebagai bahan pembelajaran untuk siswa, sebab bukan hanya menarik untuk diperhatikan karena tokoh yang bermain di dalam cerita berupa hewan, namun kita juga menambahkan nasehat-nasehat atau hikmah di dalamnya.

Pembelajaran sejarah nabi dan Rasul, mengisahkan cerita tentang nabi dan Rasul sangat menarik apabila diceritakan secara langsung, sehingga anak-anak dapat turut serta aktif bertanya apabila ada sesuatu yang ia belum pahami. Partisipasi aktif dari siswa ini menunjukkan bahwa mereka sangat tertarik untuk turut serta menyimak cerita yang di sampaikan oleh guru. Menceritakan sejarah nabi dapat kita lakukan dengan menggunakan berbagai alat peraga seperti tongkat Nabi Musa, surban Nabi Muhammad, dan juga bisa kita tampilkan dengan menggunakan media buku cerita bergambar dan lain sebagainya.

Memudahkan hafalan surat-surat pendek, mengajarkan hafalan surat-surat pendek akan lebih menarik jika kita jelaskan terlebih dahulu Asbabul nuzul dari surat yang akan kita sampaikan. Menyampaikan cerita dibalik ayat dan surat yang ada. Memberikan paparan cerita dengan menarik, akan memudahkan siswa dalam menghafalkan ayat. Sebab di dalam memori anak-anak sudah ada gambaran alur cerita dari ayat pertama sampai dengan ayat terakhir.

Anak usia dini perlu diajarkan belajar sosial melalui bercerita, mereka dilatih untuk mampu memahami masalah-masalah dan teknik untuk untuk memecahkan masalah tersebut. Tujuannya untuk menguasai pemahaman dan kecakapan dalam memecahkan masalah-masalah sosial seperti masalah dalam pertemanan, masalah dalam keluarga, masalah kelompok dan lain sebagainya (Syah, 2013, p. 120). Dalam penelitian, dongeng ternyata menyimpan banyak kearifan moral yang bisa mengetuk dunia ruhani manusia, termasuk anak-anak, untuk melihat kehidupan di dunia ini dengan pandangan yang bertumpu pada hati nurani. Sebab pada umumnya, ajaran yang terdapat pada dongeng adalah kejujuran, kasih sayang sesama manusia, kasih sayang kepada makluk hidup, termasuk hewan dan tumbuh-tumbuhan (Munawar, 


\section{Yekti Nugroho}

\section{7, p. 136).}

\section{G. Kesimpulan}

Mendongeng atau bercerita menjadi salah satu strategi pembelajaran Pendidikan Agama Islam untuk anak usia dini, Mendidik dan menasehati anak melalui cerita memberikan efek pemuasan terhadap kebutuhan akan imajinasi dan fantasi anak. Cerita dapat digunakan oleh orang tua dan guru sebagai sarana mendidik dan membentuk kepribadian anak melalui pendekatan transmisi budaya atau cultural transmision approach.

Bercerita merupakan aktivitas penting dan tidak terpisahkan dalam program pendidikan untuk anak usia dini. Berbagai manfaat dari bercerita antara lain: Membantu pembentuka pribadi dan moral anak, Membantu Kebutuhan Imajinasi dan Fantasi, Memacu Kemampuan Verbal Anak, Merangsang minat membaca dan menulis anak, Membuka cakrawala pengetahuan anak.

Untuk dapat menciptakan dongeng atau cerita yang menarik perlu dilakukan langkah-langkah tertentu diawali dengan memilih materi cerita yang sesuai dengan perkembangan anak tentunya juga dengan judul yang menarik, memahami dan menghafal isi cerita, terutama bagi pencerita pemula menghafalkan cerita menjadi sesuatu yang penting untuk dilakukan, setelah menghafal cerita kita harus meghayati karakter tokoh, dan tahap terakhir dari upaya menampilkan cerita atau mendongeng dengan baik adalah berlatih dan intropeksi.

Setelah kita melakukan persiapan sebelum bercerita kita juga harus memahami teknik dalam bercerita, diawali dengan memilih dan mempersiapkan tempat yang bersih dan nyaman, serta memastikan semua peserta didik dapat memperhatikan pencerita dengan jelas. Bercerita dapat dilakukan dengan alat peraga seperti buku, boneka, dan media lainnya, tetapi juga dapat dilakukan secara langsung tanpa alat peraga, namun ini membutuhkan kemampuan ekstra dari pencerita agar tampak enerjik dan menarik, kita juga harus mengekspresikan karakter tokoh dengan baik apakah tokoh sedang marah, kesal, bahagia atau senang dan lain sebagainya. Menirukan bunyi dan karakter suara, Menghidupkan suasana cerita, dan yang terakhir adalah Memilih diksi dan struktur kalimat, hal ini penting karena bercerita untuk anak harus memperhatikan pemilihan kata yang sekiranya mereka mengerti dan memahaminya.

Pembelajaran Pendidikan Agama Islam dengan Mendongeng, dongeng menyimpan banyak kearifan moral yang bisa mengetuk dunia ruhani manusia, termasuk anak-anak, untuk melihat kehidupan di dunia ini dengan pandangan yang bertumpu pada hati nurani. Sebab pada umumnya, ajaran yang terdapat pada dongeng adalah kejujuran, kasih sayang sesama manusia, kasih sayang 


\section{Pembelajaran Pendidikan Agama Islam

kepada makluk hidup, termasuk hewan dan tumbuh-tumbuhan. Menyampaikan materi pendidikan Agama Islam dengan strategi mendongeng atau bercerita menjadi sesuatu yang menyenangkan, strategi ini dapat kita lakukan terutama pada penyempaian materi akhlak, sejarah Nabi dan Rasul, hafalan ayat-ayat pendek, dan Asbabun nuzul surat dan ayat Al-Qur'an. 


\section{Yekti Nugroho}

\section{Daftar Pustaka}

Charner, Kathy, dkk. (2005). Permainan Berbasis Sentra Pembelajaran untuk Anak Usia 3 Sampai 6 Tahun. Jakarta. Erlangga.

Gunarti, Winny. (2009). Anak Punya Masalah Al-Qur'an Menjawab 22 Masalah Anak-Anak dan Jawabannya Berdasarkan Al-Qur'an. Jakarta: Gramedia Pustaka Utama.

Helmawati. (2014). Pendidikan Kelauraga. Bandung: Remaja Rosdakarya.

Machali Imam, dan Muhajir. (2011). Pendidikan Karakter Pengalaman Implementasi Pendidikan Karakter di Sekolah. Yogyakarta: Aura Pustaka.

Munawar, Budhi dan Rohman. (2017). Pendidikan Karakter Pendidikan Menghidupkan Nilai untuk Pesantren Madrasah dan Sekolah. Jakarta: The Asian Fondation.

Musfiroh, Tadkiroatun. (2008). Memilih Menyusun dan Menyajikan Cerita untuk Anak Usia Dini. Yogyakarta: Tiara Wacana.

Prawira, Purwa Atmaja. (2013). Psikologi Pendidikan dalam Perspektif Baru. Yogyakarta: Ar-Ruzz Media.

Santrock, John W. (2007). Psikologi Pendidikan. Jakarta: Kencana Prenada Media Group.

Setyanton, Tri. (2012). "Penggunaan Metode Bercerita bagi Anak Usia Dini di PAUD Smart Little Cilame Indah Bandung”. dalam Jurnal Empowerment. Vol. 1. Nomor 2.

Shaliha, Viana Mell. (2014). Rumah 1000 Dongeng. Yogyakarta: Laksana Kids.

Sugihastuti. (1996). Serba-Serbi Cerita Anak-Anak. Yogyakarta: Pustaka Pelajar.

Syah, Muhibbin. (2013). Psikologi Pendidikan dengan Pendekatan Baru. Bandung: Remaja Rosdakarya.

Tukiyah, Yoanna F. (2012). Kisah Indah Budi Pekerti, (Jakarta: Gramedia Pustaka Utama.

Yaumi, Muhammad. (2014). Pendidikan Karakter Landasan Pilar dan Implementasi. Jakarta: Prenadamedia. 